\title{
The Delta Model for Fresh Water Policy Analysis in the Netherlands
}

\author{
Geert Prinsen • Frederiek Sperna Weiland • Erik Ruijgh
}

Received: 14 November 2013 / Accepted: 7 November 2014/

Published online: 26 November 2014

(C) The Author(s) 2014. This article is published with open access at Springerlink.com

\begin{abstract}
During dry years, such as 2003 and the early summer of 2011, the Netherlands faces water shortages, salt intrusion, navigation limitations and problems with availability of cooling water for power plants. Considering the changing climate, the frequency of these problems is expected to increase. A policy analysis using an integrated set of models has been launched by the government: the Dutch Delta Programme. The Delta model is the consistent set of models for analysing the decisions related to the long-term fresh water supply and flood risk management of the Netherlands. The country-wide SOBEK-1D hydrodynamic surface water model (LSM) was developed as part of the Delta model and forms the link between the Netherlands Hydrological Instrument (NHI) and impact assessment models for salinity, temperature, water quality, aquatic ecology and navigation. The Delta model provides a computational facility that automates the workflow of running sets of interconnected models for the national policy analysis on fresh water and various regional programmes within the Delta Programme. The Delta model, although being computationally demanding, enabled analyses of the present situation, future scenarios (2050 and 2100) and possible adaptation measures. Moreover, the Delta model has supported consistency between the national analyses and regional analyses in the Delta Programme.
\end{abstract}

Keywords Delta Programme $\cdot$ Delta model $\cdot$ Policy analysis $\cdot$ Fresh water $\cdot$ Drought $\cdot$ Salinity

\section{Introduction}

In dry years, such as 2003 and the early summer of 2011, the Netherlands faced several water related problems. Fresh water availability declined and the irrigation demand for agriculture increased. Water use is not only restricted because of quantity limitations, but also due to quality problems. At low river discharges, the salt intrusion through the Rotterdam waterway reaches further inland, causing salinisation of important surface water intakes for drinking water supply and irrigation, thus requiring intakes to be closed. Moreover, reduced water depths in the rivers hamper navigation, and increasing water temperature (Bölscher et al. 2013) poses problems to both the energy production sector, with availability of cooling water for

G. Prinsen $(\bowtie) \cdot$ F. Sperna Weiland $\cdot$ E. Ruijgh

Deltares, PO Box 177, 2600 MH Delft, The Netherlands

e-mail: geert.prinsen@deltares.nl 
power plants, and drinking water intake (Penailillo Burgos et al. 2010). In view of the changing climate the frequency of these problems is expected to increase (Bresser et al. 2006; De Wit et al. 2007).

A policy analysis was launched by the Dutch government to address these issues: the Dutch Delta Programme. Within the Dutch Delta Programme, the Delta Plan for the 21st century in the Netherlands has been developed. It proposes a safe and attractive Netherlands, now and tomorrow, where fresh water supply, flood risk management and spatial planning are organised effectively (Van Alphen 2012, 2014; Delta Programme Commissioner 2012). This policy analysis requires a quantification of the severity of water related problems in order to set priorities and identify the main tipping points and their timing (Kwadijk et al. 2010; Haasnoot et al. 2012).

To this end, it was decided to develop a multi-disciplinary modelling system - the Delta model - that allows for climate and policy scenario analysis as well as exploration of possible adaptation strategies. The Delta model is one of the first model suites that (1) covers a nationwide water system (both surface and subsurface) to study fresh water supply and flood risk management; (2) integrates multiple use sectors-i.e. agriculture, navigation, drinking water, industry, ecology, energy, and flood protection-; (3) enables scenario analysis and the exploration of adaptation options; and (4) is supported and accepted by modellers, (regional) water managers and policy makers.

The Delta model is not an entirely new model; it rather combines and re-uses the available models. These models have been developed over many years and include a wide range of concepts, schematisations and datasets. The main objective of the Delta model is to combine the original models in a consistent set of models, impact assessment models and databases (Fig. 1), to support the consistency of the Delta Programme. In this paper we will discuss the feasibility to develop an integrated computer modelling system that meets all the above mentioned demands, with a focus on the models for fresh water supply.

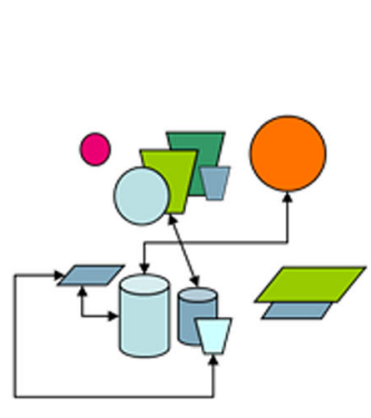

original situation

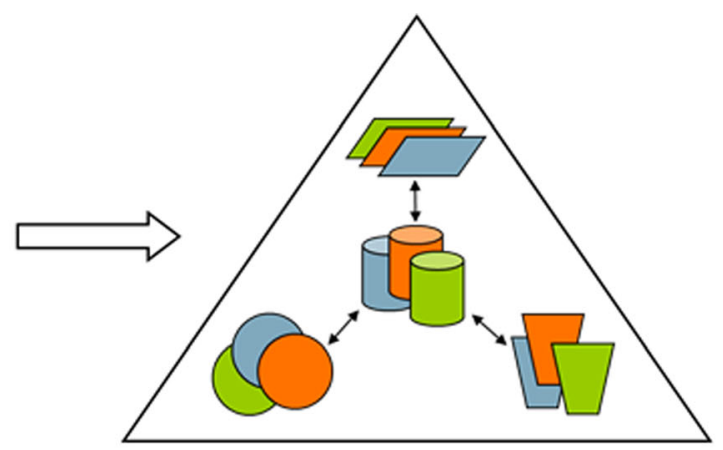

Deltamodel
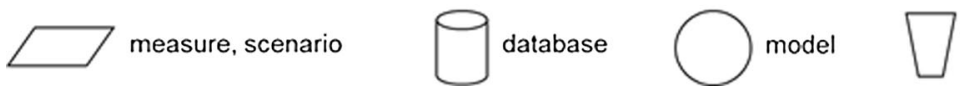

impact assessment

Fig. 1 The development of the Delta model from the original situation to a consistent set of measures, scenarios, databases, models and impact assessment models for (in different colours) fresh water supply, flood risk management and spatial planning 
In literature, only a few nation-wide modelling systems comparable with the Delta model can be found. Within the Netherlands, a first national water modelling instrument was developed after the dry summer of 1976-the PAWN instrument (Abrahamse et al. 1982). This instrument supported the Policy Analysis for Water in the Netherlands (PAWN; Pulles 1985) and simulated water distribution over the country depending on water availability, demand and the capacity of the water system (De Lange et al. 2014).

Another example is the Danish National Water Resources Model that intends to be a reference for all water related management issues at all management levels within Denmark (Højberg et al. 2012). It is a combined surface and groundwater model developed in MIKE SHE/MIKE 11 based on national datasets. All model simulations are stored in a publicly accessible database comparable to the Dutch Delta Portal (http://www.deltaportaal.nl/) where the summarized results of the Delta model are presented.

In Belgium, an integrated modelling system that comprises all catchment processes of relevance for integrated water resources management is developed in OpenMI (Safiolea et al. 2011). A first application for water quality modelling in the river Zenne can be found in Leta et al. (2014). The system allows for data exchange between models at runtime.

In Australia, a national Water Resources Assessment (AWRA) System is currently being developed (Van Dijk and Renzullo 2011). The AWRA system produces readily interpretable water balance estimates used for the National Water Account as well as regular water resource assessments. The system includes a spatial landscape hydrology model (AWRA-L) that produces estimates of water storage in the soil, shallow groundwater and streams. Models and data are integrated in the environmental data and modelling platform Delft-FEWS (Werner et al. 2013) and aggregated data is made available in the AWRA data portal (http://connect. csiro.au/water/thredds/).

In the US, the National Science Foundation recently funded a research project that focuses on the development of an integrated computer modelling system for water resources management. The system should seamlessly connect models for hydrology, engineering, economics, public policy, agriculture, ecology, chemistry and other disciplines. All models and data are planned to be coupled online with OpenMI (Castranova et al. 2013).

The above mentioned systems show similarities to the Dutch Delta model, even though the systems are all built around (existing) country specific water system models. Similar to the Australian AWRA system, the Dutch Delta model is developed within Delft-FEWS to enable efficient exchange of data and model outputs. Although foreseen, online data exchange between running models with OpenMI-similar to the Belgium and American systems - is not yet possible in the Delta model. To share the results of the Delta model with a wider audience, the model results are aggregated to seasonal and annual average values for a number of districts covering the Netherlands and presented in a public data portal comparable to the Danish and Australian portals. Finally, all the systems are supposed to support policy analysis and water management processes, however publications on the evaluation of the application of the systems are limited.

In this paper, we will first discuss the design and development of the Dutch Delta model for the Delta Programme on fresh water supply, we will then evaluate its ability to support policy making and finally we will discuss the value of a complex high resolution modelling system for policy making. 


\section{The Delta Model for the Delta Programme on Fresh Water}

\subsection{Delta Programme on Fresh Water}

Although the Netherlands in general has an abundance of water, in dry years, water shortages do occur. In the future these shortages are expected to increase due to climate change (Bresser et al. 2006). The prevailing climate scenarios for the Netherlands all assume that summers will become drier. Also, discharges of the rivers Rhine and Meuse at the Dutch border are expected to reduce in summer (Görgen et al. 2010; De Wit et al. 2007). Another aspect of climate change is the sea level rise. In the Rhine-Meuse estuary some drinking water intakes and regional intakes are at present already threatened by too high salinity levels in dry periods (Beijk 2008). In May-June 2011, the Scheelhoek drinking water intake in the Haringvliet was temporarily stopped due to high salinity at the intake location. In May-June 2011 and in August-September 2003, the important regional intake at Gouda was closed. Salt intrusion from the Rotterdam Waterway had reached the intake at Gouda (see Fig. 2). In the future, due to sea level rise, lower river discharges in summer and less rainfall in summer, the frequency and intensity of drought and salinity problems are expected to increase. The Delta Programme on fresh water is studying the Dutch water system for the years 2050 and 2100 and aims to find long-term solutions and strategies to face these drought and salinity challenges.

The Delta model is the consistent set of models for the whole Delta Programme. Figure 3 presents an overview of the model components for the Delta Programme on fresh water, including the impact assessment models and the data-exchanges between them. The various components are discussed in more detail below.

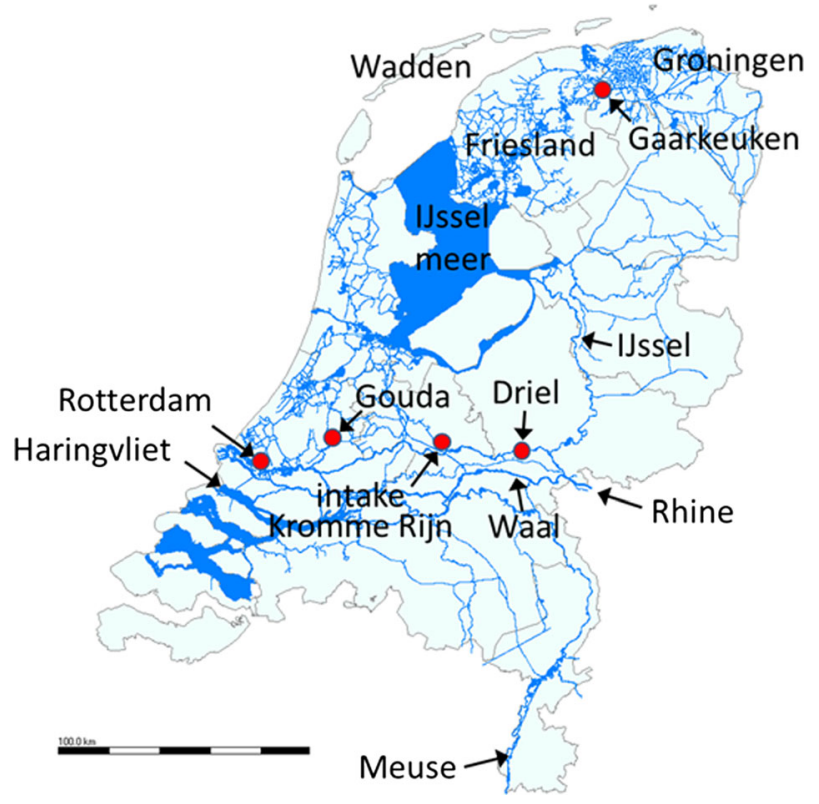

Fig. 2 Surface water system of the Netherlands (in blue lines), with some specific locations mentioned in this paper 


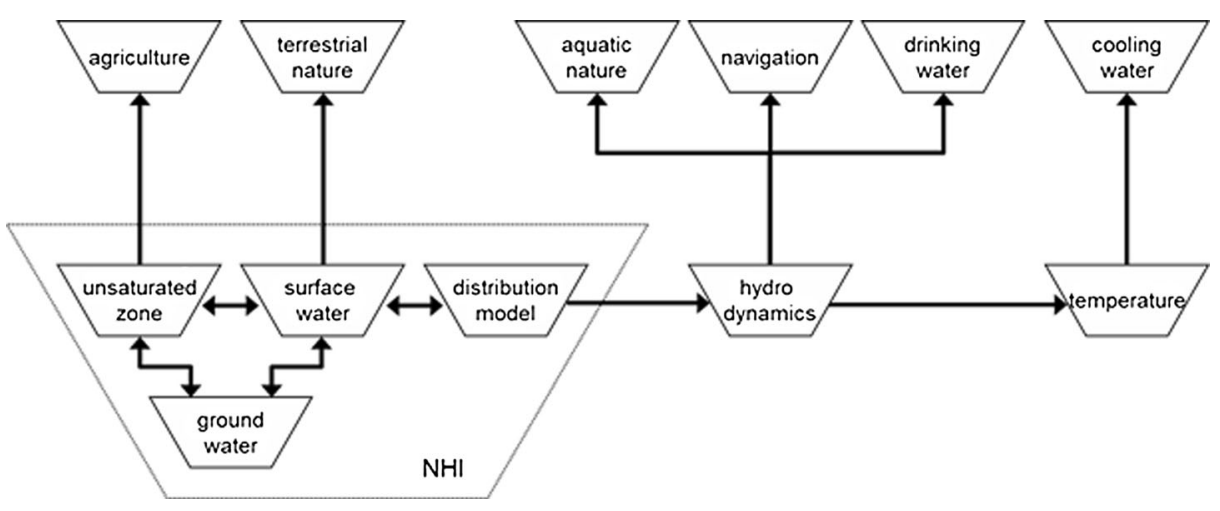

Fig. 3 Overview of Delta model components for the Delta Programme on fresh water

\subsection{The Delta Scenarios}

The Dutch Meteorological Institute developed the Dutch climate scenarios (Te Linde et al. 2011). This is a set of four scenarios considered representative for the full set of (down-scaled) IPCC SRES AR4 scenarios (IPCC 2007). The KNMI'06 scenarios have been derived from RCM model runs from the European PRUDENCE project (Christensen et al. 2011) which are based on the IPCC4 scenarios. From the set of model runs, representative RCM runs have been selected that project a large (W) and moderate temperature increase $(\mathrm{G})$ and change $(+)$ and no change () in atmospheric circulation. These RCM runs have been used to modify historical observed meteorological time-series by mapping of the 10th, 50th and 90th quantile (Van den Hurk et al. 2006; Lenderink et al. 2007).

The upstream model boundary conditions for the Rhine and Meuse for the current and future climate have been derived from these meteorological time-series using the HBV models for the full Rhine and Meuse catchments (Te Linde et al. 2010, 2011; De Wit et al. 2007). For the downstream boundary conditions, the observed hourly water level time series have been used and for the future time series the projected sea level rise has been added to all hourly values as a constant.

The climate scenarios are combined with socio-economic scenarios. Together, they form the so-called Delta scenarios which are used in the Delta Programme and Delta model (Deltares 2011). The Delta scenarios are constructed from two climate scenarios and two socio-economic scenarios. The climate scenarios $\mathrm{G}$ and $\mathrm{W}+$ are selected for this purpose. Climate scenario $G$ projects moderate climate change. For 2050 , scenario $G$ assumes $1^{\circ}$ temperature increase and $15 \mathrm{~cm}$ sea level rise relative to 1990; for 2100, the scenario assumes $2^{\circ}$ temperature increase and $35 \mathrm{~cm}$ sea level rise relative to 1990 . The scenario $\mathrm{W}+$ assumes a quicker and more extreme climate change: $\mathrm{W}+2050$ assumes the same temperature increase and sea level rise as G2100, and $\mathrm{W}+2100$ assumes $4^{\circ}$ temperature increase and $85 \mathrm{~cm}$ sea level rise. In addition, the $\mathrm{W}+$ scenario assumes more extreme precipitation events in winter. The economic scenarios are a low growth scenario- $\mathrm{G}-$ (a sustainable developing society with little population growth) and a larger growth scenario-W+- (larger population growth and a heterogeneous society where the focus is on economy first). In the Delta Programme on fresh water these scenarios are reflected in changing land use, changing meteorological forcing, changing upstream river discharge for the Rhine and Meuse and smaller rivers at the borders, sea level rise and land subsidence. In order to cope with all these changes, new water resources management strategies for the Netherlands are required. 


\subsection{Netherlands Hydrological Modelling Instrument NHI}

The Netherlands Hydrological modelling Instrument (NHI) is an integrated model for groundwater, unsaturated zone, regional surface water and water distribution (Fig. 3). Below follows a short description; for the full description we refer to De Lange et al. (2014). The groundwater model is based on Modflow-2005 (Harbaugh 2005). The unsaturated zone model MetaSwap (Van Walsum and Groenendijk 2008) is based on the physics of the SWAP model (Kroes et al. 2008). Small regional surface water bodies are modelled using MOZART (Dutch acronym for model of the unsaturated zone). The Distribution Model (DM) is used to model the water balances of large rivers and distribution canals.

NHI computes the groundwater and unsaturated zone balances on a $250 \times 250 \mathrm{~m}$ grid using a daily time step. The regional water systems in MOZART are modelled using 8500 local surface waters located in 250 districts. The districts are linked with intake locations and discharge locations in the DM schematisation. DM determines the optimized surface water distribution in the main system based on water availability, water demands, priorities and distribution rules. MOZART allocates surface water within the subcatchments to the end users based on the amount allocated by DM and the demand priorities. Surface water in NHI is typically modelled using a 10-day time step.

NHI developments started in 2006 as a joint effort by Deltares, Alterra, the Centre for Water Management of the Dutch Ministry of Infrastructure and the Environment (Rijkswaterstaat, Waterdienst) and PBL, the Netherlands Environmental Assessment Agency. An important step in the first phase was to come to a common groundwater model of the Netherlands, and to link that to the already existing surface water models of the Rijkswaterstaat Waterdienst. Coming from the situation where each institute had its own groundwater model, it took some time to come to a common groundwater model based on MODFLOW. At present, NHI developments are supported not only by the already mentioned institutes and national authorities, but also by the entire Dutch water sector including regional water authorities and drinking water companies.

\subsection{Hydrodynamic SOBEK Model LSM}

The desire to model the surface water distribution system in more detail than in the present Distribution Model (DM) already existed for a number of years. In 2010, the development of a national hydrodynamic surface water model with the SOBEK software package (http://www. deltaressystems.com/hydro/product/108282/sobek-suite) started. This model is called LSM, which is the Dutch abbreviation for nationwide Sobek model. LSM provides more detail than $\mathrm{DM}$, both in spatial and temporal resolution with a typical computational timestep of $10 \mathrm{~min}$ and a typical spatial resolution of $500 \mathrm{~m}$. The hydrodynamic SOBEK model LSM calculates discharges, water levels and depths based on the results of NHI. A first version of LSM has already been applied in first analyses for the Delta Programme on fresh water (Prinsen and Becker 2011).

The development of the detailed LSM is the result of close cooperation with the regional water authorities. They provided readily available schematisations of their main surface water system. LSM was extended using these regional models in 2012. The models were linked together in one large model schematisation of the whole of the Netherlands. The present LSM consists of about 21,000 calculation points and takes $18 \mathrm{~h}$ to compute 1 year. ${ }^{1}$ The

\footnotetext{
${ }^{1}$ This computation time is achieved on a 64 bits PC with Windows 7 Service Pack 1, Intel core i7-2600 CPU, $3.4 \mathrm{GHz}$ and $16 \mathrm{~Gb}$ RAM.
} 
development process involved several sessions with all regional authorities and individual contacts of each party involved. Figure 4 shows the level of detail in DM and in LSM. From the picture, it is clear that the modelled surface water system is modelled quite coarse by DM, and quite detailed by LSM. The regional water authorities recognize their own water system much better in the more detailed LSM and they have confidence in LSM since it is based on their own models.

The district water allocations as computed by DM and MOZART are passed as lateral extractions and lateral discharges to LSM. The regional intake and outlet structures in LSM are set to maintain regional water levels. LSM thus computes the water levels and discharges corresponding to the optimised water allocation, using the details of the hydrodynamic model. Validation results and comparison of LSM and DM are discussed in Section 3 of this paper.

\subsection{Impact Assessment Models}

The impact assessment modules use the water balance and distribution calculated with NHI and LSM (see also Fig. 3). Two models directly use the output of NHI (agriculture and terrestrial nature), the other impact assessment models use results of the LSM model.

\subsubsection{Agriculture}

The impact assessment model for agriculture is AGRICOM (Van Bakel et al. 2009). The model calculates agricultural damage caused by drought, extreme rainfall (water logging) and salinisation. Part of the model input is generated by NHI (see Table 1). In addition, the model uses national maps with soil types and crop specific land use. The output of AGRICOM is combined with economic information (e.g. water prices, crop prices) to calculate the agricultural damage in euros.

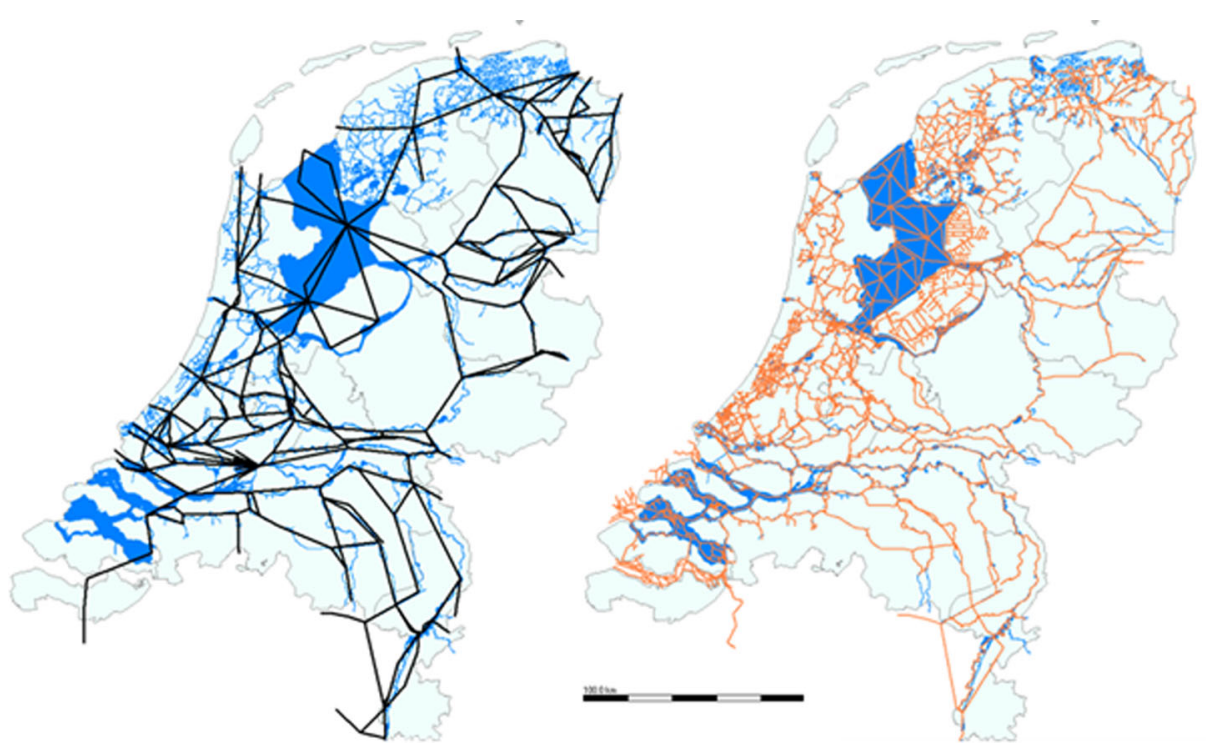

Fig. 4 Distribution model DM schematisation (left, black lines) and LSM schematisation (right, orange lines) of the Netherlands 
Table 1 Connections between individual models within the Delta model

\begin{tabular}{|c|c|c|c|c|}
\hline Connection & Exchange variables & Units & $\begin{array}{l}\text { Spatial } \\
\text { resolution }\end{array}$ & $\begin{array}{l}\text { Temporal } \\
\text { resolution }\end{array}$ \\
\hline $\mathrm{NHI} \rightarrow$ AGRICOM & $\begin{array}{l}\text { - Groundwater levels } \\
\text { - Potential evaporation } \\
\text { - Actual evaporation } \\
\text { - Irrigation from surface water } \\
\text { - Irrigation from groundwater } \\
\text { - Cl concentration }\end{array}$ & $\begin{array}{l}\mathrm{m} \text { NAP } \\
\mathrm{mm} / \text { day } \\
\mathrm{mm} / \text { day } \\
\mathrm{mm} / \text { day } \\
\mathrm{mm} / \text { day } \\
\mathrm{mg} / 1\end{array}$ & $\begin{array}{l}250 * 250 \mathrm{~m} \\
250 * 250 \mathrm{~m} \\
250 * 250 \mathrm{~m} \\
250 * 250 \mathrm{~m} \\
250 * 250 \mathrm{~m} \\
250 * 250 \mathrm{~m}\end{array}$ & $\begin{array}{l}\text { daily } \\
\text { daily } \\
\text { daily } \\
\text { daily } \\
\text { daily } \\
\text { daily }\end{array}$ \\
\hline $\mathrm{NHI} \rightarrow$ DEMNAT & $\begin{array}{l}\text { - Groundwater levels } \\
\text { - Surface water levels }\end{array}$ & $\begin{array}{l}\text { m NAP } \\
\text { m NAP }\end{array}$ & $\begin{array}{l}250 * 250 \mathrm{~m} \\
250 * 250 \mathrm{~m}\end{array}$ & $\begin{array}{l}\text { daily } \\
\text { daily }\end{array}$ \\
\hline $\begin{array}{l}\mathrm{NHI} \rightarrow \mathrm{LSM} \\
\mathrm{LSM} \rightarrow \text { HABITAT }\end{array}$ & $\begin{array}{l}\text { - Lateral surface water fluxes } \\
\text { - Discharges } \\
\text { - Surface water levels }\end{array}$ & $\begin{array}{l}\mathrm{m}^{3} / \mathrm{s} \\
\mathrm{m}^{3} / \mathrm{s} \\
\mathrm{m} \text { NAP }\end{array}$ & $\begin{array}{l}3361 \text { locations } \\
3 \text { locations }\end{array}$ & $\begin{array}{l}10 \text { days } \\
\text { daily } \\
\text { daily }\end{array}$ \\
\hline $\mathrm{LSM} \rightarrow$ BIVAS & $\begin{array}{l}\text { - Water depths } \\
\text { - Surface water levels } \\
\text { - Flow velocity }\end{array}$ & $\begin{array}{l}\mathrm{m} \\
\mathrm{m} \text { NAP } \\
\mathrm{m} / \mathrm{s}\end{array}$ & $\begin{array}{l}227 \text { locations } \\
227 \text { locations } \\
114 \text { locations }\end{array}$ & $\begin{array}{l}\text { daily } \\
\text { daily } \\
\text { daily }\end{array}$ \\
\hline $\begin{array}{l}\text { LSM } \rightarrow \text { Drinking water } \\
\text { LSM } \rightarrow \text { LTM }\end{array}$ & $\begin{array}{l}\text { - Cl concentration } \\
\text { - Flow velocity } \\
\text { - Discharges } \\
\text { - Water levels } \\
\text { - Water depths }\end{array}$ & $\begin{array}{l}\mathrm{mg} / 1 \\
\mathrm{~m} / \mathrm{s} \\
\mathrm{m}^{3} / \mathrm{s} \\
\mathrm{m} \\
\mathrm{m} \text { NAP }\end{array}$ & $\begin{array}{l}54 \text { locations } \\
22000 \text { loc. } \\
22000 \text { loc. } \\
21000 \text { loc. } \\
21000 \text { loc. }\end{array}$ & $\begin{array}{l}10 \mathrm{~min} \\
\text { daily }\end{array}$ \\
\hline LTM $\rightarrow$ Cooling water & $\begin{array}{l}\text { - Water temperature } \\
\text { - Available heat discharge capacity }\end{array}$ & $\begin{array}{l}{ }^{\circ} \mathrm{C} \\
\mathrm{W} / \mathrm{s}\end{array}$ & $\begin{array}{l}177 \\
\text { locations }\end{array}$ & daily \\
\hline
\end{tabular}

\subsubsection{Terrestrial Nature}

DEMNAT is the acronym for Dose Effect Model Nature Terrestrial (Witte et al. 1992; Van Ek et al. 1996). The DEMNAT model predicts ecological effects of changes in hydrology. Hereto, it combines information on vegetation, soil types and hydrology. DEMNAT has been configured on a national level. Part of the model input is generated by NHI (see Table 1). The model considers changes in, amongst others, mean spring groundwater level, upward seepages, changes in surface water level of local water bodies and the intake of river water into local water bodies. Changes are expressed as botanical quality, i.e. the completeness and occurrence of 18 pre-defined ecotopes.

\subsubsection{Aquatic Nature}

HABITAT is a spatial impact assessment model for aquatic nature (Haasnoot and Van de Wolfshaar 2009; Haasnoot et al. 2009). It computes the suitability and quality of the environment for various species and ecotopes. It is possible to incorporate influences of human interventions and autonomous developments, such as climate change. The model combines information on ecotope occurrence, salinity, nutrient concentrations and hydrological conditions, such as flood frequency, inundation period and water depths. Model results are expressed as ecotope suitability. Part of the model input is generated by LSM (see Table 1): output for daily mean discharges and daily mean water level is translated to inundation 
duration (days) and seasonal water levels for HABITAT. The current version of the Delta model includes a HABITAT model for Lake IJsselmeer.

\subsubsection{Navigation}

BIVAS is an economic model for the navigation sector (Miete et al. 2013). It calculates economic losses due to the following limitations: (1) in periods of low water depths, ships can be loaded less heavily, so more ship movements or other means of transport are needed; and (2) in periods of high flows, bridges may limit the ship transport capacity. The model contains a pre-defined set of ships and a pre-defined load that has to reach a number of different destinations. The main output used within the Delta model is the (change in) costs to transport the entire load. BIVAS uses water depth and water level time-series computed by LSM as input (see Table 1).

\subsubsection{Drinking Water}

Salt intrusion in the Rhine-Meuse estuary during periods of low river discharges leads to higher chloride concentrations. These concentrations are relevant for a number of drinking water and industrial water intakes. The impact assessment module for drinking water and industry determines the frequency and duration of exceedance of chloride concentration threshold values at important intake locations. Chloride concentrations are calculated with a hydrodynamic model, configured in the SOBEK software that covers the Rhine-Meuse estuary where the influence of salt intrusion from the sea is largest.

\subsubsection{Cooling Water}

The national water temperature model-LTM - calculates water temperatures for the larger rivers and streams within the Netherlands (Boderie and Visser 2007; Penailillo Burgos et al. 2010). It uses the water distribution computed by LSM, temperature and precipitation timeseries from the Delta scenarios, projected changes in air humidity and radiation from the IPCC 4 th assessment report and information on thermal discharges from industry and electricity power plants to determine surface water temperatures. The results of LTM are translated into the frequency and duration that a pre-defined temperature threshold is exceeded. This temperature threshold corresponds to water temperatures above which additional heat discharge is not allowed. The LTM model approach has also been used for scenario simulations for other sections of the Rhine River (Badde et al. 2014).

\subsection{FEWS Application}

The modelling chain of the Delta Programme on fresh water is implemented in the environmental data and modelling platform Delft-FEWS (Werner et al. 2013). Delft-FEWS was originally developed as a Flood Early Warning System (FEWS). Due to its capabilities of handling a variety of different input data formats, efficient data storage, statistical data analysis functionalities, graphical visualisation tools, and its ability to exchange model in- and output and to run a variety of environmental models, it was considered suitable for climate scenario analysis application as well (Sperna Weiland et al. 2012; Weerts et al. 2010). The connection between Delft-FEWS and the different models is arranged through model adapters which enable exchange of model input and output data and communicate run commands based on user-selected choices. Many adapters already exist and for the fresh water part of the Delta 
model, the Delft-FEWS platform only had to be extended with a new model adapter for the communication with the navigation module BIVAS.

\section{Model Validation and Results}

\section{$3.1 \mathrm{NHI}$}

NHI (De Lange et al. 2014) has been validated for the hydrological years 1996-2006 (Hoogewoud et al. 2012, 2013). The validation covered comparison with observations for aspects such as groundwater level dynamics, actual evapotranspiration (both field data and satellite based computations), sprinkling from surface water and groundwater, surface water discharges at important intake and discharge points, water levels in Lake IJsselmeer and salinity (Hoogewoud et al. 2013). For surface water discharges, the Nash-Sutcliffe (NS) performance indicator (Bennett et al. 2013) and the cumulative volumetric difference between model and observations were used. NS model efficiency is $>0.5$ for $60 \%$ of the locations and $>0.2$ for $80 \%$ of the locations. Cumulative differences between model and observations are than $10 \%$ (discharge) or $25 \%$ (supply) for $80 \%$ of the locations. These values meet the requirements specified by the Ministry of Infrastructure and the Environment. Special attention was paid to the dry year 2003, since NHI is used as the central model in the Delta Programme on fresh water, which focuses on solving the issues of drought and salinisation. The NHI results for surface water allocations to and discharges from the 250 districts are converted to some 3361 lateral flows for the LSM model (see also Table 1).

\subsection{LSM}

Using the NHI results as described above, LSM has been run for the year 2003 to compute the water distribution in more detail, and to feed the impact assessment models with proper information. The discharges of the Rhine, Meuse and several small border-crossing rivers are upstream boundary conditions for LSM. The downstream boundary conditions are observed sea water levels (optional with additional projected sea level rise). LSM computes the water distribution by operating the structures such that the desired lateral extractions are met, and desired water levels are maintained as good as possible. Even in dry periods, most of the Rhine discharge eventually flows to the sea through the Rotterdam waterway, the Haringvliet sluices or the sluices of Lake IJsselmeer. In the validation of LSM, these main locations have been checked, and, in addition, many regional intakes and discharge points have been validated (Prinsen 2013). Figure 5 and Table 2 show a selection of results for some interesting locations.

In order to make a comparison with DM also the NS values for LSM decade average flows are given in the table. In general the decade-based NS values are better than the daily-based NS
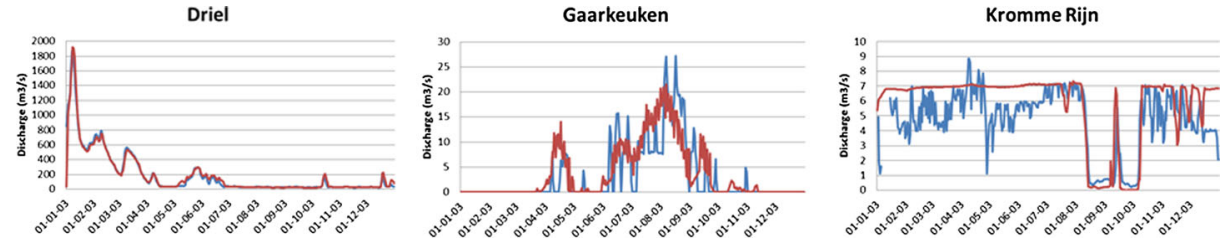

Fig. 5 LSM results compared with measurements (blue = LSM, red = observed), year 2003 
Table 2 Nash-Sutcliffe performance indicators for DM and LSM for some selected locations, for the whole year 2003 and summer (May-September) only

\begin{tabular}{lllllll}
\hline Location & $\begin{array}{l}\text { LSM } \\
\text { daily }\end{array}$ & $\begin{array}{l}\text { LSM- } \\
\text { decade }\end{array}$ & $\begin{array}{l}\text { DM } \\
\text { decade }\end{array}$ & $\begin{array}{l}\text { LSM daily } \\
\text { summer }\end{array}$ & $\begin{array}{l}\text { LSM-decade } \\
\text { summer }\end{array}$ & $\begin{array}{l}\text { DM decade } \\
\text { summer }\end{array}$ \\
\hline Driel & 0.96 & 0.99 & 0.99 & 0.87 & 0.90 & 0.86 \\
IJsselmeer-Wadden Sea & 0.31 & 0.80 & 0.78 & 0.40 & 0.66 & 0.62 \\
Gaarkeuken intake & 0.56 & 0.77 & 0.49 & 0.44 & 0.72 & 0.48 \\
Kromme Rijn intake & 0.09 & 0.25 & -0.26 & 0.68 & 0.78 & -0.05 \\
Gouda intake & 0.78 & 0.84 & 0.75 & 0.73 & 0.78 & 0.63 \\
Bodegraven intake & 0.72 & 0.67 & -0.16 & 0.60 & 0.63 & -0.71 \\
Delfland intake & 0.60 & 0.73 & 0.84 & 0.51 & 0.66 & 0.76 \\
\hline
\end{tabular}

values, since the differences in the day-to-day dynamics are now averaged per decade. Looking at the decade-based NS values, LSM performs better than DM for most locations.

The weir at Driel in the Nederrijn River is a main distribution point. The operation of the weir determines the distribution of the Rhine water over the Waal, Nederrijn and IJssel branches. In periods of low discharges the weir is operated to maintain a minimum flow at the Nederrijn river and to maximise the flow over the IJssel to Lake IJsselmeer. Both in DM and LSM the flow at Driel is modelled very well with NS values of 0.86 and higher.

The location at Gaarkeuken in the north of the Netherlands (see Fig. 2) is a critical location on the water supply route from Lake IJsselmeer to the province of Groningen. Both DM and LSM perform satisfactory for this location with Nash-Sutcliffe values of approximately 0.5 or higher. Also the cumulative differences are acceptable.

A location which does not perform satisfactory in terms of Nash-Sutcliffe values is the intake Kromme Rijn (see Fig. 2). The Nash-Sutcliffe values of DM are even negative, meaning that the average value of the observations would be a better prediction than the model. The Nash-Sutcliffe of LSM is already better, but still relatively low when considering the whole year. Given the goal of the model, it is considered very important that the intake limitation in the period August-September 2003 and the availability in the short period in between is actually reproduced very well by the model. This is reflected in the high NS values for the summer period (May-September). The reason for the relatively low Nash-Sutcliffe value for the whole year is that the intake dynamics in the remaining part of the year is not reproduced very well. Where the model shows a more or less constant intake, the observations show an erratic pattern. But for the purpose of fresh water policy analysis, focussing on the summer dry periods, the performance is acceptable.

LSM performs clearly better than DM for the intake Kromme Rijn and the intake Bodegraven (north of Gouda) since operation of these structures is better represented in the hydrodynamic LSM than in the demand-driven, priority-based DM. The intake capacity of the Kromme Rijn is limited at low water levels in the Nederrijn River. This aspect is difficult to include in DM, since DM does not compute water levels except for the large storage reservoirs. In DM, the intake Bodegraven only supplies the computed demand and nothing more, while in LSM the operation of the intake is in line with the current practice that intake pumps are switched on at full capacity when the intake is activated.

In general, the model has a quite good match with the observed data, although there are of course locations where larger differences are found and the model can be improved. Differences between model results and observations are sometimes caused by typical 
operational aspects. For instance, in practice, the timing of changing from winter target levels to summer target levels is flexible, whereas the model is quite rigid. If a rise in target level is defined in the input of the model to take place after April 1, any excess water on March 31 will be discharged by the model, whereas in reality the water authorities may decide to keep that excess water in anticipation of the desired target level rise the next days (and thus reducing the demand for the next days). Operation of structures is still sometimes difficult to model. In September 2003, the Bodegraven intake north of Gouda (see Fig. 2) was switched off for a short while because the model only looked at the actual conditions; in reality, the water authorities also take predictions into account and the intake at Bodegraven remained open. Such operational aspects are considered less important for the policy analyses.

\subsection{Impact Assessment Models}

As shown in Fig. 3 and Table 1, the impact assessment models for agriculture and terrestrial nature use the results of NHI, and the impact assessment models for aquatic nature, navigation, drinking water and cooling water use the results of LSM. The development, maintenance and validation of the impact assessment models are managed by the developers of these models. The Delta model focussed on the integration of the impact assessment models into one consistent modelling environment. Rather than improving the various impact assessment models, it has been ensured that each model uses the same forcing from NHI and LSM. In a later stage, the consistency of the spatial and temporal resolution of the assessment models may be improved. The accuracy of the impact assessment models will be evaluated in the near future through expert workshops similar to the ones organized for the earlier national impact assessment for fresh water (Klijn et al. 2012).

This method is followed because most of the impact assessment models produce numbers that cannot directly be verified with available measured data (i.e. occurrence of specific ecotopes, economic losses due to navigation problems, agricultural losses). The temperature model is the only impact model that has been evaluated in a quantitative way using both graphical comparison of results and straightforward criteria like mean error (BIAS) and mean absolute error (MAE) (Bennett et al. 2013). At almost all measurement locations, the mean absolute error is less than $1{ }^{\circ} \mathrm{C}$ (Boderie and Visser 2007) which is considered satisfactory.

\subsection{From Model Results to Policy Analysis and Decision Making}

The Delta model produces time-series of different water system variables such as discharge, water level, temperature, ecotope occurrence, agricultural damage and navigation costs, at many locations (see also Table 1). These variables are not ready to be used in decision making. Within the policy analysis, the model outputs are translated to relevant indicators, such as:

- Water shortage

- Damage for agriculture, navigation, industry

- Availability of cooling water / drinking water

- Changes in nature / ecotopes

To assess the value of these indicators, the high resolution model outputs are aggregated in time and in space to 17 regions in the Netherlands (Ter Maat et al. 2014). These indicators are used in the policy analysis in order to answer the question whether the current water management will be sustainable under changing climate and socio-economic conditions and where adaptation measure are required. Results of the policy analysis have been aggregated 
further to 5 regions that cover the Netherlands and are assumed to be representative for decision making.

\section{Use of the Model-Discussion}

The Delta model has facilitated and will in future further facilitate the national policy analyses within the Delta Programme for fresh water supply (as well as flood risk management). The support of regional water managers was gained by involving them during the development of the Delta model and by including their regional models in the Delta model. By including these regional models, high resolution modelling of all relevant processes is provided, which is a prerequisite for the implementation and evaluation of (detailed) regional adaptation measures.

However, there is a price to be paid. The use of less accurate, lower resolution models would have strongly reduced computation (and analysis) times and would have enabled faster scanning of potential adaptation measures and scenario analysis. In addition, it would have reduced the required amount of data storage capacity. Moreover, future changes in climate, land-use, dike and river bed elevation are highly uncertain and might affect model parameterisation and results. The implementation of these uncertain changes in high resolution models is challenging, even if (partly) automated.

It should also be noted, that the detailed calculation results of the Delta model have been aggregated for the policy analysis and subsequently summarized to higher levels interpretable for decision makers. During this process, the high resolution information is lost. Based on these observations, policy analysers and decision makers argued that lower resolution models or metamodels can be sufficient for policy planning (Davis and Bigelow 2003; Haasnoot et al. 2012).

Taking all these aspects into account, the high resolution models have been included in the Delta model, as the support of the regional water managers is based on the use of the high resolution models. Their support is considered essential for the acceptance of the recommendations of the Delta Programme. In addition, it is noted that for detailed planning and design of structural adaptation measures the current suite of models provides the required resolution.

However, we also conclude from our experiences during the development and application of the Delta model that the present computation times sometimes hamper the analyses. For instance, long time series analyses are not very attractive, so some of the analyses have been done using representative years. Several options have been identified to reduce the calculation times:

- it might be possible to reduce the calculation time of NHI by replacing the $250 * 250 \mathrm{~m}$ grid (with timestep of 1 day) for the groundwater model (Modflow) with a $1 * 1 \mathrm{~km}$ grid (timestep of 10 days);

- the schematisation of LSM can be limited to those sections of the surface water system that are relevant for the water distribution. For this reason, LSM-light has already been developed, with a calculation time of some $15 \%$ of the complete LSM;

- a review of all data flows might be useful, as the calculation time will benefit when less data is written in output files. Moreover, less time is required to analyse these data, and less disk space is required to store all the data.

In comparison with other nationwide integrated water modelling systems, the Delta model is quite advanced: it integrates multi-sectoral water models and by using Delft-FEWS as a computational platform interaction between models is automated in a user-friendly environment similar to the Australian system (Van Dijk and Renzullo 2011). Similar to the Belgian 
and US systems, we have started to explore the possibilities to improve the model by implementing OpenMI (Castranova et al. 2013) as model interface between at least the ground- and surface water models to enable model interaction at run-time. Moreover, OpenMI could be used to connect high resolution regional models with the lower resolution model of the main water system, or to connect LSM to NHI.

From the overall process it is clear that the output of an integrated modelling decision support system does not provide ready to use information for decision makers. The up-scaling of the model outcomes to representative indicators (damage and losses) and information of relevance for decision makers is still required.

\section{Conclusions}

The Dutch Delta model includes a consistent set of hydrological, hydraulic and impact assessment models that successfully supported the policy analysis for the Delta Programme on fresh water. The implementation in Delft-FEWS allowed for a transparent coupling of models, data handling, efficient storage of data and visualization and analysis of results.

Although the resolutions of the computation models do not match the resolution of information required for decision making, the support of the regional water managers was gained by the use of the high resolution models and considered essential for the acceptance of the recommendations of the Delta Programme. Moreover, to evaluate regional measures the high resolution models were requisite. In future research, we will further explore possibilities to optimize the equilibrium between calculation times, model resolutions and possibilities for fast screening of scenarios and adaptation strategies.

Open Access This article is distributed under the terms of the Creative Commons Attribution License which permits any use, distribution, and reproduction in any medium, provided the original author(s) and the source are credited.

\section{References}

Abrahamse A, Van Beek E, Baarse G (1982) Policy analysis of water management for the Netherlands. In: Model for regional hydrology, agricultural water demands and damages from drought and salinity, vol XII. Rand Corporation and Delft Hydraulics, Delft

Badde U, Bergfeld-Wiedemann T, Boderie P, Brahmer G, Demuth N, Haag-Wanka I, Krahe P (2014) Estimation of effects of climate change scenarios on future Rhine water temperature development, Summary Report (report 213en, ISBN-Nr 978-3-941994-52-2) and Extensive Version (report 214en, ISBN-Nr 3-941994-530), International Commission for Protection of the Rhine (ICPR), Koblenz, Germany, 2014. http://www.iksr. org/uploads/media/213en.pdf, http://www.iksr.org/uploads/media/214_en_01.pdf. Accessed 14 Nov 2014

Beijk V (2008) Klimaatverandering en verzilting. Rijkswaterstaat Waterdienst en Rijkswaterstaat DZH, The Netherlands (in Dutch)

Bennett ND, Croke BFW, Guariso G, Guillaume JHA, Hamilton SH, Jakeman AJ, Marsili-Libelli S, Newham LTH, Norton JP, Perrin C, Pierce SA, Robson B, Seppelt R, Voinov AA, Fath BD, Andreassian V (2013) Characterising performance of environmental models. Environ Model Softw 40:1-20. doi:10.1016/j.envsoft. 2012.09.011

Boderie P, Visser T (2007) Implementatie verbeteringen in het landelijk temperatuur model. Delft Hydraulics report Q4421, Delft, The Netherlands. (in Dutch) http:/www.helpdeskwater.nl/publish/pages/15474/ implementerenverbeteringeninlandelijktmodelbibliotheek.pdf. Accessed 14 Nov 2014

Bölscher T, Van Slobbe EJJ, Van Vliet MTH, Werners SE (2013) Adaptation turning points in river restoration? The Rhine salmon case. Sustain 5:2288-2304. doi:10.3390/su5062288

Bresser AHM, Berk MM, van den Born GJ, van Bree L, van Gaalen FW, Ligtvoet W, van Minnen JG, Witmer MCH, Amelung B, Huynen MMTE, Bolwidt L, ten Brinke W, Buiteveld H, Dillingh D, van Dorland R, 
Leemans R, van Strien A, Vermaat J (2006) The effects of climate change in the Netherlands. PBL Netherlands Environmental Assessment Agency, The Netherlands

Castranova AM, Goodall JL, Ercran MB (2013) Integrated modelling within a hydrologic information system: an OpenMI based approach. Environ Model Softw 39:263-273. doi:10.1016/j.envsoft.2012.02.011

Christensen JH, Carter T, Giorgi F (2011) PRUDENCE employs new methods to assess European climate change. Eos 83:147. doi:10.1029/2002EO000094

Davis PK, Bigelow JH (2003) Motivated metamodels, synthesis of cause-effect reasoning and statistical metamodelling. RAND Corporation, Santa Monica

De Lange WJ, Prinsen GF, Hoogewoud JC, Veldhuizen AA, Verkaik J, Oude Essink GHP, Van Walsum PEV, Delsman JR, Hunnink JC, Masson HTL, Kroon T (2014) An operational, multi-scale, multi-model system for consensus-based, integrated water management and policy analysis: the Netherlands hydrological instrument. Environ Model \& Softw 59:98-108. doi:10.1016/j.envsoft.2014.05.009

De Wit MJM, Van den Hurk B, Warmerdam PMM, Torfs PJJF, Roulin E, Van Deursen WPA (2007) Impact of climate change on low flows in the river Meuse. Clim Chang. doi:10.1007/s10584-006-9195-2

Delta Programme Commissioner (2012) Working on the Delta. Deltaprogramme 2013. The road towards the Delta Decisions. Dutch Ministry of Infrastructure and the Environment and the Ministry of Economic Affairs, Agriculture and Innovation, The Hague, The Netherlands. http://www.deltacommissaris.nl/english/ Images/Delta\%20Programme\%202013\%20EN_tcm310-334162.pdf. Accessed 14 Nov 2014

Deltares (2011) Deltascenarios - an exploration of possible physical and socio-economical developments in the 21 st century, Deltares report 1204151.002, Delft, The Netherlands (in Dutch) https://publicwiki.deltares.nl/ download/attachments/4882623/Deltascenario's_final.pdf. Accessed 14 Nov 2014

Görgen K, Beersma J, Brahmer G, Buiteveld H, Carambia M, De Keizer O, Krahe P, Nilson E, Perrin C, Lammersen R, Volken D (2010) Assessment of climate change impacts on discharge in the Rhine River Basin: results of the RheinBlick2050 project. KHR-Schriften Bd. I-23, Koblenz and Lelystad http://www. chr-khr.org/en/file/613/download?token=U1Kev7hc0De1XtwF3JPXpLOsCNO-2Bm1-KdsQxncllo. Accessed 14 Nov 2014

Haasnoot M, Van de Wolfshaar K (2009) Combining a conceptual framework and a spatial analysis tool, HABITAT, to support the implementation of river basin management plans. Int J River Basin Manag 7(4):295-311

Haasnoot M, Verkade JS, De Bruin KM (2009) HABITAT, a spatial analysis tool for environmental impact and damage assessment. 7th ISE \& 8th HydroInformatic Conference, Chile http://oss.deltares.nl/documents/ 131795/347446/hasnoot2_2009.pdf. Accessed 14 Nov 2014

Haasnoot M, Van Deursen PA, Middelkoop H, Van Beek E, Wijermans N (2012) An integrated assessment metamodel for developing adaptation pathways for sustainable water management in the Lower Rhine Delta. In: Seppelt R, Voinov AA, Lange S, Bankamp D (eds), Conference proceedings - International Congress on Environmental Modelling and Software. Managing Resources of a Limited Planet: Pathways and Visions under Uncertainty. Sixth Biennial Meeting, Leipzig, Germany, ISBN: 978-88-9035-742-8 http:/www.iemss. org/society/index.php/iemss-2012-proceedings. Accessed 14 Nov 2014

Harbaugh AW (2005) MODFLOW-2005, the U.S. Geological Survey modular groundwater model-the groundwater flow process: U.S. Geological Survey Techniques and Methods, Chapter 16 of Book 6. Modeling techniques, Section A. Ground Water, Reston, Virginia, http://pubs.usgs.gov/tm/2005/tm6A16/ PDF/TM6A16.pdf. Accessed 14 Nov 2014

Højberg AL, Troldborg L, Stisen S, Christensen BBS, Henriksen HJ (2012) Stakeholder driven update and improvement of a national water resources model. Environ Model Softw 40:202-213. doi:10.1016/j.envsoft. 2012.09.010

Hoogewoud JC, de Lange WJ, Veldhuizen A, Prinsen GF (2012) Netherlands hydrological modeling instrument. Geophys Res Abstr 14, EGU 2012-13489, Vienna, Austria, http://meetingorganizer.copernicus.org/ EGU2012/EGU2012-13489.pdf. Accessed 14 Nov 2014

Hoogewoud JC, Prinsen GF, Hunink JC, Veldhuizen AA, van der Bolt FJE, de Lange WJ (2013) NHI 3.0 toetsing maart 2013. Deltares report 1206107-000 (in Dutch), Utrecht, The Netherlands. http://www.nhi.nu/ documenten/1206107-000-BGS-0011-DEF-Toetsingsrapportage\%20NHI\%203.0.pdf. Accessed 14 Nov 2014

IPCC (2007) Climate change 2007: the Physical Science Basis. Contribution of Working Group I to the Fourth Assessment Report of the Intergovernmental Panel on Climate Change. Solomon, S, Qin D, Manning M, Chen Z, Marquis M, Averyt KB, Tignor M, Miller HL (eds.). Cambridge University Press, Cambridge, United Kingdom and New York, NY, USA, 996 pp. http://www.ipcc.ch/pdf/assessment-report/ar4/wg1/ar4 wg1_full_report.pdf. Accessed 14 Nov 2014

Klijn F, van Velzen E, ter Maat J, Hunink JC (2012) Zoetwatervoorziening in Nederland, aangescherpte landelijke knelpuntenanalyse 21e eeuw. Deltares report 1205970-000 (in Dutch), Delft, The Netherlands. https://publicwiki.deltares.nl/download/attachments/77238371/ZWV2012.pdf?version= 1\&modificationDate=1340786741000. Accessed 14 Nov 2014 
Kroes JG, van Dam JC, Groenendijk P, Hendriks RFA, Jacobs CMJ (2008) SWAP version 3.2 Theory Description and User Manual. Alterra report 1649, Wageningen, the Netherlands. http://edepot.wur.nl/ 39776. Accessed 14 Nov 2014

Kwadijk JCJ, Haasnoot M, Mulder JPM, Hoogvliet MMC, Jeuken ABM, Van der Krogt RAA, Van Oostrom NGC, Schelfhout HA, Van Velzen EH, Van Waveren H, de Wit MJM (2010) Using adaptation tipping points to prepare for climate change and sea level rise: a case study in the Netherlands. Wiley Interdiscip Rev Clim Chang 1(5):729-740. doi:10.1002/wcc.64

Lenderink G, Van Ulden A, Van den Hurk B, Keller F (2007) A study on combining global and regional climate model results for generating climate scenarios of temperature and precipitation for the Netherlands. Clim Dyn 29:157-176. doi:10.1007/s00382-007-0227-z

Leta OT, Shrestha NK, De Fraine B, Van Griensven A, Bauwens W (2014) Integrated water quality modelling of the River Zenne (Belgium) using OpenMI. In: Philippe Gourbesville, Jean Cunge, Guy Caignaert (eds)., Advances in Hydroinformatics SINMYDRO 2012 - New Frontiers of Simulation, Springer Hydrogeology, pp 259-274. doi: 10.1007/978-981-4451-42-0_22

Miete O, Bolt E, Van der Sligte R, Turpijn B, Verheij H (2013) BIVAS, a versatile traffic assignment model for inland navigation traffic. SMART RIVERS Conference 2013, Maastricht- Belgium, 23-27 September 2013. in: Philippe Rigo and Milou Wolters (eds), Abstract Booklet. http://www.pianc.org/downloads/sailingahead/ Sailing\%20Ahead\%20June\%202013/PIANCSMART\%20Rivers\%20Booklet\%20of\%20Abstracts.pdf. Accessed 14 Nov 2014

Penailillo Burgos R, Boderie P, Rijk S, Loos S (2010) Effects of climate change on water temperature and its consequences for drinking water production. EGU General Assembly 2010, Held 2-7 May, Vienna, Austria. Geophys Res Abstr 12, EGU2010-12403-1 http://meetingorganizer.copernicus.org/EGU2010/EGU201012403-1.pdf. Accessed 14 Nov 2014

Prinsen GF (2013) Achtergronddocument LSM 1.04. Deltares report 1207765-004-ZWS-0001 (in Dutch), Delft, The Netherlands. http://www.helpdeskwater.nl/publish/pages/30836/201303_achtergronddocument_lsm_1. pdf. Accessed 14 Nov 2014

Prinsen GF, Becker BPJ (2011) Application of sobek hydraulic surface water models in the Netherlands hydrological modelling instrument. Irrig Drain 60(Suppl 1):35-41. doi:10.1002/ird.665

Pulles JW (1985) Policy analysis for the water management in the Netherlands (PAWN). Rijkswaterstaat, Den Haag

Safiolea E, Baki S, Makropoulos C, Deliege JF, Magermans P, Everbecq E, Gkesouli A, Stamou A, Mimikou M (2011) Flexible, component-based integrated modeling for river basin management planning. ICE Water Manag J 164(8):405-419. doi:10.1680/wama.2011.164.8.405

Sperna Weiland F, Van Beek LPH, Weerts AH, Bierkens MFP (2012) Extracting information from an ensemble of GCMs to reliably assess future global runoff change. J Hydrol 412-413:66-75

Te Linde AH, Aerts JCJH, Bakker AMR, Kwadijk JCJ (2010) Simulating low probability peak discharges for the Rhine basin using resampled climate modeling data. Water Resour Res, 46 (WR03512) Wiley. doi:10.1029/ 2009WR007707 http://onlinelibrary.wiley.com/doi/10.1029/2009WR007707/pdf. Accessed 14 Nov 2014

Te Linde A, Van der Brugge R, Haasnoot M, Bruggeman W (2011) Balancing science and policy while developping Delta Scenarios for the Netherlands. World Delta Summit, Jakarta

Ter Maat J, Van der Vat M, Hunink J, Haasnoot M, Prinsen G, Visser M, Boderie P, Van Ek R, Maarse M, Van der Sligte R, Verheij H, Wesselius C (2014) Effecten van maatregelen voor de zoetwatervoorziening in Nederland in de 21e eeuw. Deltares report 1209141 (in Dutch), Delft, The Netherlands

Van Alphen (2012) Elevating delta management in national planning. World Water Week, Stockholm, http:// www.worldwaterweek.org/documents/WWW_PDF/2012/Wed/managing-delta/Jos-van-Alphen-DeltaProgramme.pdf, Accessed at 10 Jul 2014 Presentation at World Water week

Van Alphen (2014) The Delta Programme and updated flood risk management policies in the Netherlands. ICFM6, Sao Paulo, Brazil. http://www.abrh.org.br/icfm6/proceedings/papers/PAP014368.pdf. Accessed 14 Nov 2014

Van Bakel PJT, Linderhof V, Van’t Klooster CE, Veldhuizen AA, Goense D, Mulder HM. Massop HTL (2009). Definitiestudie AGRICOM, Alterra-rapport 1934, Wageningen, The Netherlands (in Dutch). http://edepot. wur.n1/50811. Accessed 14 Nov 2014

Van den Hurk B, Klein Tank A, Lenderink G, Van Ulden A, VanOldenborgh GJ, Katsman C, Van den Brink H, Keller F, Bessembinder J, Burgers G, Komen G, Hazelegger W, Drijfhout S (2006) KNMI Climate Change Scenarios 2006 for the Netherlands, KNMI Scientific Report WR 2006-01. Royal Netherlands Meteorological Institute, De Bilt

Van Dijk AIJM, Renzullo LJ (2011) Water resource monitoring systems and the role of satellite observations. Hydrol Earth Syst Sci 15:39-55. doi:10.5194/hess-15-39-2011

Van Ek R, Witte JPM, Runhaar J, Klijn F, Nienhuis JG, Pakes U (1996) DEMNAT-2.1, latest innovations on a national dose-effect model for the analysis of dehydration of wetlands in the Netherlands. In: Holzmann H, Nachtnebel HP (eds), Applications of geographical information systems in hydrology and water resources 
management, HydroGIS ‘96, Vienna, Austria, pp 358-365 https://publicwiki.deltares.nl/download/ attachments/77238371/hgis96p.pdf?version=1\&modificationDate=1340787212000\&api=v2. Accessed 14 Nov 2014

Van Walsum PEV, Groenendijk P (2008) Quasi steady-state simulation of the unsaturated zone in groundwater modeling of lowland regions. Vadose Zone J 7(2):769-781

Weerts AH, Schellekens J, Sperna Weiland F (2010) Real-time geospatial data handling and forecasting: examples from DELFT-FEWS forecasting platform/system. IEEE J Sel Top Appl Earth Obs Remote Sens 3(3):386-394. doi:10.1109/JSTARS.2010.2046882

Werner M, Schellekens J, Gijsbers P, Van Dijk M, Van den Akker O, Heynert K (2013) The Delft-FEWS flow forecasting system. Environ Model Softw 40:65-77. doi:10.1016/j.envsoft.2012.07.010

Witte JPM, Klijn F, Claessen FAM, Groen CLG, Meijden R (1992) A model to predict and assess the impacts of hydrologic changes on terrestrial ecosystems in The Netherlands, and its use in a climate scenario. Wetl Ecol Manag 2(1-2):69-83. doi:10.1007/BF00178137 